\title{
Study About HPLC Method Elaboration and Validation for Acid Lactic Assay in Grape J uice Fermentation Process
}

\author{
SANDA RODICA BOTA, ALINA CLAUDIA COZMA*, ALINA MARIA CARABAN \\ University of Oradea, Faculty of Sciences, Chemistry Department, 1 Universitatii Str., 410087, Oradea, Romania \\ In the present study, a simple and fast HPLC procedure has been developed for determination of a wide \\ range of lactic acid concentrations. During the lactic acid analysis, the analytic column, YMC-Pack ODS AQ, \\ was operating at $20^{\circ} \mathrm{C}$. The mobile phase, $0.03 \% \mathrm{H}_{3} \mathrm{PO}_{4}$ :acetonitrile (88:12), was delivered isocratic, at a \\ flow rate of $0.5 \mathrm{~mL} / \mathrm{min}$, in a $25 \mathrm{~min}$ run. The method was validate. The method could successfully used to \\ quantify lactic acid in grape juice during fermentation.
}

Keywords: Lactic acid, HPLC, grape juice

Lactic acid was discovered in 1780 by Swedish chemist, Carl Wilhelm Scheele, who isolated the lactic acid from sour milk as an impure brown syrup and gave it a name based on its origins: Mjolksyra. The French scientist Fremy produced lactic acid by fermentation and this gave rise to industrial production in 1881. Lactic acid is produced by the fermentation of sugar and water or by chemical process and is commercially usually sold as a liquid [1,2].

It is present in many foods both naturally or as a product of in situ microbial fermentation, as in sauerkraut, yogurt, buttermilk, sourdough breads and many other fermented foods. Is also a major metabolic intermediate in most living organisms, from anaerobic prokaryotes to humans. Lactic acid exists naturally in two optical isomers: $\mathrm{d}(-)$ - lactic acid and I $(+)$-lactic acid. Since elevated levels of the $d$ isomer are harmful to humans, $\mathrm{I}(+)$-lactic acid is the preferred isomer for food-related and pharmaceutical industries $[3,4]$.
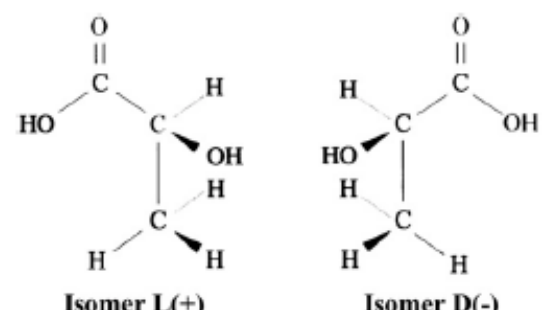

Fig. 1. Structure of $D(-)$ and $L(+)$ isomers of the lactic acid

It is the simplest 2-hydroxycarboxylic acid with a chiral atom and exists oin two enantiomeric firms (Fig.1). The chemical behavior of lactic acid is determined by its physico-chemical properties, amog which are: acidic character in aqueous medium, bifunctional reactivity associates with the presence of a carboxyl and a hydroxyk group, which gives it great reaction versatility and asymmetric optical activity od C2.

Lactic acid as a chemical is also considered a commodity with a growing market. Chemical synthesis of lactic acid results in a racemic mixture of the two isomers, while the fermentation process can yield an optically pure form of lactic acid or racemate, depending on microorganisms, substrates and fermentation conditions employed in the production process [5]. It is usually used in food industry as mild acid flavour, $\mathrm{pH}$ regulator or as a preservative. Poly lactic acid (PLA), an emerging product from lactic acid is used in the manufacture of biodegradable plastics. Fermentation of glucose from starch hydrolysate is the new production process for lactic acid. This state-of-theart production process has replaced the older chemical synthesis, e.g. the addition of hydrogen cyanide to acetaldehyde and the subsequent hydrolysis of the resulting lactonitrile [6-10].

Is also used in a wide range of food applications such as bakery products, beverages, meat products, confectionery, dairy products, salads, dressings, ready meals, etc. In food products usually serves as either as a $\mathrm{pH}$ regulator or as a preservative. It is also used as a flavoring agent.

Pure and anhydrous racemic lactic acid is a white crystalline solid with a low melting point. Lactic acid has two optical forms, $L(+)$ and $D(-)$. $L(+)$-lactic acid is the biological isomer as it is naturally present in the human body [11].

Titrimetric methods, gas chromatography, colorimetric analysis and enzymatic methods are examples of techniques that are used for analyses of organic acids in food. How ever, because of simplicity and speed of analysis, the HPLC techniques is an attractive method, which requires a minimum of sample preparation prior to separation and permits quantitative determination of organic acids in a short time [12,13].

There are numerous chromatographic methods for the determination of shortchain fatty acids (mostnotably lactic acid) in foodstuffs).

Gas chromatography (GC) has been widely used to great effect but can suffer from the need to derivatise the polar carboxylic acid group prior to analysis

Liquid chromatography (LC) and especially ion exclusion chromatography (IEC) has been the preferred technique for the separation of short chain fatty acids, in many food related products $[14,15]$.

\section{Experimental part}

Materials and methods

The HPLC chromatography method was used to quantitative analysis of lactic acid in various foods and in fermentation environments, These determinations were performed by HPLC chromatography ACME 9000 chromatograph consisting of: modul gradient pump, modul UV-Vis detector, YMC-Pack ODS AQ 150-4.6 S-5 $\mu \mathrm{m}$ column, determination at $210 \mathrm{~nm}$.

\footnotetext{
* email: alinacozma69@yahoo.com, Phone: 0744457791
} 


\section{Materials and reagents}

All chemicals were of analytical grade and organic solvents were of HPLC grade. Lactic acid (LA), were purchased from Sigma Aldrich. Methanol, acetonitrile and phosphoric acid were purchased from Merck.

\section{Standard preparation}

The working solution was prepared in concentration of $0.06,0.12,0.18,0.27,0.36$ with stock solution preparea at a concentration of $0.45 \mathrm{mg} / \mathrm{L}$ by dissolving lactic acid în $0.03 \% \mathrm{H}_{3} \mathrm{PO}_{4}$ solution. Then $20 \mu \mathrm{l}$ of the solution was injected into the apparatus and a standard calibration curve was created based on the peak area of the chrmatogram.

\section{HPLC-UV analysis}

Chromatographic separation was tested YMC-Pack ODS AQ 150-4.6 column with particle sizes of S-5 $\mu \mathrm{m}$ The mobile phase consisted of $0.03 \% \mathrm{H}_{3} \mathrm{PO}_{4}$ in HPLC water $(A)$ and acetonitrile (B), $A: B=88: 12$. The $U V$ detector was set at a wavelength of $210 \mathrm{~nm}$.

\section{In-house method validation}

The proposed quantitative method was validated inhouse for lactic acid, by a set of parameters (i.e. limit of quantification (LOQ), limit of detection (LOD), linearity, precision and accuracy) that were in compliance with the recommendations as defined by the European Community and with reference guidelines defined in other EU and FDA documents .

\section{Limit of quantification (LOQ)}

The LOQ was defined as the lowest concentration of lactic acid for which the method was validated with a precision and accuracy that fell within the recommended ranges [16].

\section{Limit of detection (LOD)}

The LOD was defined as the lowest concentration of each organic acid thatcould be recognized by the detector with a signal-to-nois $(S / N)$ ratio of $\geq 3[16]$.

\section{Linearity}

The linearity of the method was evaluated by creating an external calibration curve, which were prepared at the following concentration levels: $0.06 \mathrm{mg} / \mathrm{ml}, 0.12 \mathrm{mg} / \mathrm{ml}$, $0.18 \mathrm{mg} / \mathrm{ml}, 0.27 \mathrm{mg} / \mathrm{ml}, 0.36 \mathrm{mg} / \mathrm{ml}$ and $0.45 \mathrm{mg} / \mathrm{ml}$. The calibration curve samples were treated in a similar way to the study samples. All calibrator samples were injected once on the HPLC-UV instrument. The correlation coefficient ( $r$ ) was determined and had to be $\geq 0.99$ [16].

\section{Accuracy and precision}

The precision was determined by measuring the precision of recordings carried aut on an intraday and interday basis. The intraday precision was calculated using data from five iterative analyses of standard lactic acid at a low $(0.06 \mathrm{mg} / \mathrm{ml})$ and high $(0.45 \mathrm{mg} / \mathrm{ml})$ concentration level on the same day, while the interday precision was calculated by observing the solution after three days. The final precision values were calculates as a percentage of the relative standard deviation (\%RSD) [16].

\section{Results and discussions}

Lactic acid is miscible in the water. The solutions containing LA $(100.0 \mu \mathrm{g} / \mathrm{ml})$ scanned separately at a wavelength range of 400-200 nm using ultraviolet spectrophotometer (AnalytikJ ena Specord 210 plus) to determine the maximum wavelength of LA. The maximum wavelength ( $\lambda \max$ ) was found to be $210 \mathrm{~nm}$.

Were made determinations with various mobile phase compositions in order to determine the optimum composition for efficient separation. The best results were obtained with the mobile phase composed of component A $0.03 \%$ aqueous phosphoric acid and component B, acetonitrile, in a ratio of 88:12. For the present study thr flow rate was $0.5 \mathrm{ml} / \mathrm{min}$. Under these conditions a suitable retention time is obtained $\left(R_{t}=4.1 \mathrm{~min}\right)$.

The linearity data are presented in Table 1 . As can be seen from the table, the linearity of the method, tested at five concentration calibration levels for lactic acid, is satisfactory in all cases with coefficients of determination $\left(R^{2}=0.9998\right)$.

Precision was tested on five replicated analyses of lactic acid standard at a low $(0.06 \mathrm{mg} / \mathrm{ml})$ and high $(0.45 \mathrm{mg} /$ $\mathrm{ml}$ ) concentration level. The RSD values ranged from 1.20 and 1.33, in same day and 1.42 and 2.07 for another day indicating that the method was precise with a high degree of repeatability, (RSD <2\%) (Table 2).

Table 1

CONCENTRATION RANGES OF LINEAL RESPONSE

\begin{tabular}{|l|c|c|c|c|c|c|}
\hline Conc(mg/ml) & 0,06 & 0,12 & 0,18 & 0,27 & 0,36 & 0,45 \\
\hline Area & 635044 & 1228084 & 1867144 & 2805716 & 3796288 & 4777867 \\
\hline
\end{tabular}

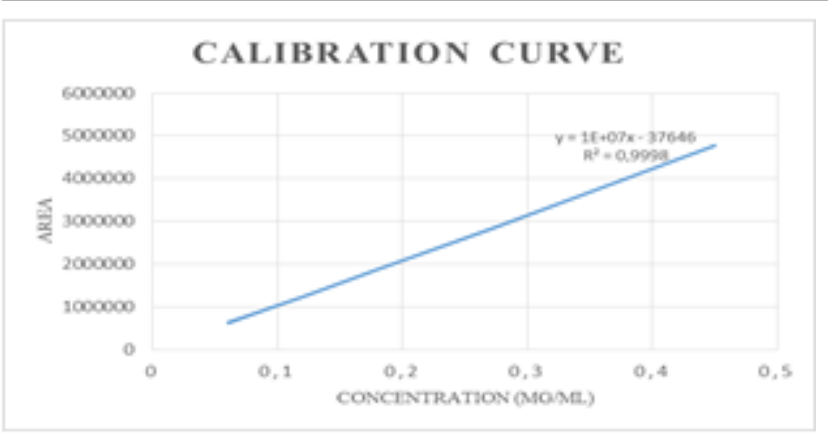

Fig. 1. Calibration curve for lactic acid

\begin{tabular}{|c|c|c|c|c|c|c|}
\hline conc & Intraday & After 3 day & conc & Intraday & After 3 day & \multirow{9}{*}{$\begin{array}{c}\text { Table } 2 \\
\text { RSD VALUES }\end{array}$} \\
\hline & Area & Area & & Area & Area & \\
\hline \multirow[t]{5}{*}{$0,06 \mathrm{mg} / \mathrm{ml}$} & 636944 & 646789 & $0.45 \mathrm{mg} / \mathrm{ml}$ & 4782665 & 4792216 & \\
\hline & 639654 & 623381 & & 2808961 & 4888542 & \\
\hline & 621745 & 637237 & & 4676942 & 4736412 & \\
\hline & 644112 & 621156 & & 4806982 & 4717512 & \\
\hline & 632764 & 649972 & & 2813787 & 4753651 & \\
\hline Average & 635044 & 635707 & & 4777867 & 4777667 & \\
\hline RSD(\%) & 1,3388 & 2,0694 & & 1,2074 & 1,4196 & \\
\hline
\end{tabular}




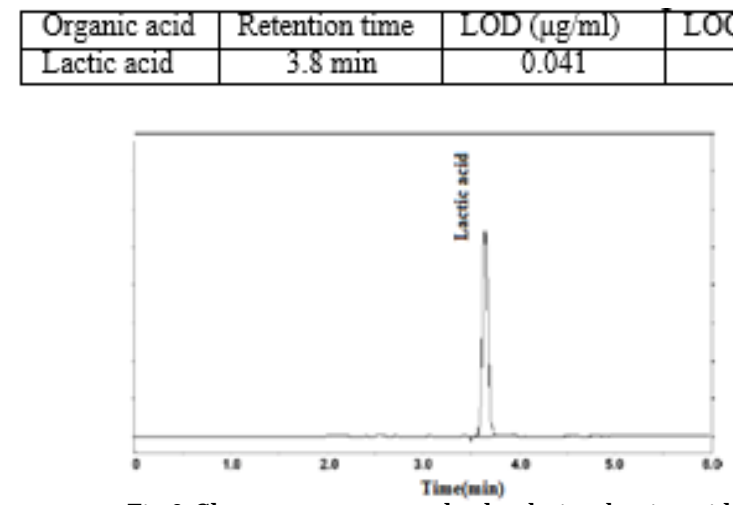

Fig.2 Chromatogram standard solution lactic acid

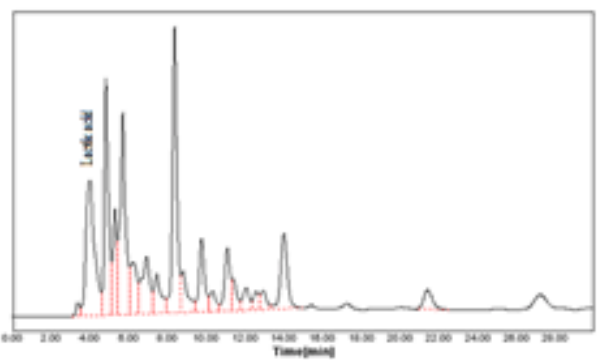

rig. 3. Chromatogram ot grape juice

\begin{tabular}{|l|c|c|c|c|}
\hline Time & 1 day & 2 day & 3 day & 4 day \\
\hline Concentration & $0.387 \mathrm{mg} / \mathrm{ml}$ & $0.411 \mathrm{mg} / \mathrm{ml}$ & $0.433 \mathrm{mg} / \mathrm{ml}$ & $0.439 \mathrm{mg} / \mathrm{ml}$ \\
\hline
\end{tabular}

Table 4

RESULTS OF GRAPE JUICE DURING FERMENTATION

The detection limit (LOD) could be defined as the smallest peak detected with a signal height three times that of the baseline, while the limit of quantification (LOQ) referred to the lowest level of analyte which could be de-termined with an acceptable degree of confidence. In the present work, detection limits were estimated according to the hypothesis that a peak, to be detected, should have a signal-to-noise ratio $>3$ (table 3 ).

The optimized and validated method was applied to the analysis of lactic acid during fermentation of grape juice. Table 4 summarizes the concentration variation of lactic acid during fermentation.

In this fermentation proces, the content of lactic acid increases in grape juice.

Good linearity, precision and accuracy of the method confirmed its suitability for analysis of organic acids grape juice and wines. The optimized and validated method was applied on determination of lactic acid during grape juice fermentation, observing differences in the content that can be attributed mainly to different fermentation proceses in vinification practices.

\section{Conclusions}

This work is a contribution to the development of a rapid and precise HPLC procedure for quantitative determination of lactic acid in grapes juices under reverse phase conditions. Lactic acids have been determined and eluted from the column within 25 minutes. Considering the easiness and conciseness of sample preparation, the proposed analytical procedure could be considered as an efficient, accurate and rapid method of organic acid deter-mination.

The method could successfully used to quantify lactic acids in grape juice during fermentation.

Acknowledgement: This work has been supported under the PNCDI III Programme P2 - Experimental demonstration project (PN-III P2-2.1198PED / 2017) funded by UEFISCDI, Romania.

\section{References}

1.*** http://www.lactic-acid.com/history.html

2.DATTA, R., HENRY, M., J. Chem Technol Biotechnol, 81, 2006, p.1119 1129 .

3.DIABA, F., MONTIEL, J.A., SERBAN G., BONJ OCH J., Org. Lett., 17, 2015, p.3860-3863.

4.YIN, P., NISHINA, N., KOSAKAI, Y., YAHIRO, K., PAKR, Y., OKABE, M., Journal of Fermentation and Bioengineering, 84, no.3 1997, p.249253.

5. BAYITSE, R., International J ournal of Applied Science of Technology, 5, no.1, 2015, p.165-175.

6.MARTINEZ, F.A.C., BALCIUNAS E. M., SALGABO, J. M., GONZALEZ, J. M. D., CONVERTI, A., OLIVEIRA, R. P. S, Trends in Food Science \&Technology, 30, 2013, p. 70-83.

7. QUIROS, A. R., LAGE-YUSTY, M. A., LÓPEZ-HERNÁNDEZ, J. Talanta, 78, no.2, 2009, p.643-646.

8. SCHERER, R., RYBKA, A.C.P., BALLUS, C.A., MEINHART, A.D., FILHO, J.T., GODOY, H.T., Food Chemistry, 135, 2012, p. 150-154.

9. ZAMONOVA, M.K., GLOTOVA V.N., IZHEMBINA T.N., NOVIKOV V.T, Procedia chemistry, 10, 2014, p. 244-251.

10. ASHOOR, S.H., WELTY, J., J Chromatogr, 287, no.2,1984, p. 452-456 11. KIM, H.J ., LEE, M.J ., CHO, S.K., J Chromatogr Sep Tech, 8, no.,5, 2017, p.385.

12. LIAWRUANGRATH, P., LIAW RUAGRATH, B., LIAWRUANGRATH, S., CHIANG MAI J. Sci., 42, no.1,2015, p. 208-215.

13. GEZGINC, Y., TOPCAL, F., COMERTPAY, S., Akyol, I., J Dairy Sci., 98, no. 3, 2015, p. 1426-1434.

14. SHUI, G., LEONG, L.P., JOURNAL OF CHROMATOGRAPHY A, 997, no.1, 2002, p.89-96.

15. LINGET, C., NETTER, C., HEEMS, D., VÉRETTE, E., Analusis, 26, no.1, 1988, p. 35-39.

16.GOCAN, S., Cromatografia de inaltã performanta, partea II; Cromatografia de lichide pe coloanã, Editura Dacia, Cluj-Napoca, 2002.

Manuscript received: 6.12 .2018 